\title{
The Utilization of Mobile Money Services in Small Scale Enterprises: A Case Study
}

\author{
${ }^{1}$ Suryakanthi Tangirala, ${ }^{2}$ Samuel Nlondiwa
}

\begin{abstract}
Mobile money is an electronic wallet service that allows users to store, send and receive money using their mobile phone. This research is an effort to find out the adoption and utilization of mobile money services in small sized enterprises located in Gaborone, Botswana. Inevitably, other aspects such as different types of transactions carried out using mobile money services in small business, customer's perception on quality of mobile money service providers, impeding factors of mobile money adoption are also studied for wider understanding of the subject. The findings of the study show that small enterprises use mobile money services to carry out transactions but the level of adoption is not significant. The study revealed that transactional costs and connectivity issues are major barriers of adoption of mobile money services. In conclusion the study recommended that the service providers must improve the connectivity issues and reduce transaction charges in order to increase the utilization of mobile money services
\end{abstract}

Index Terms-Mobile Money, Orange Money, Myzaka, electronic payment.

\section{INTRODUCTION}

The new era of globalization seems to be driven by economies of free market capitalism, international trade and investment. Due to internet, telecommunications and mobile technologies the speed and scope of globalization has increased exponentially. Mobile money services marked new frontiers in mobile technology as economic activity expands globally because of the increase of number of micro businesses using it in carrying out transactions with enhanced speed and ease.

Mobile money is an electronic wallet service that facilitates users to store, send and receive money using their mobile phones. It is considered as an alternative for bank accounts for safe and easy electronic payments with no limitation on type of mobile being used. These services are usually offered by local mobile telecom operators who have a license to operate electronic payment services [1]

M-PESA, a mobile phone based money transfer, financing and micro financing service in Kenya revolutionized the mobile money service since their introduction in 2007 and this new technological innovation has improved the quality of lives of many people through enabling commerce and reducing financial exclusion. Mobile money is available in many countries and is more popular in places where people are less likely to have bank accounts. According to [2] only about 5\% of Tanzania's

Published on November 21, 2019.

Authors are with University of Botswana, Gaborone, Botswana

Emails: ${ }^{1}$ tangiralas@ub.ac.bw ; ${ }^{2}$ samlatelwa@gmail.com population has a bank account, whilst in Ethiopia the ratio of banks to people is one to a hundred thousand people mobile money services have thus helped to close the gap left by banking and financial institutions in delivering the financial intermediation role they are traditionally supposed to play within an economy. According to a report by Boston consulting group [3], the Sub-Saharan African region has high mobile phone penetration levels when compared to the adoption of formal banking account registrations. As such mobile money services remain as the major tool for facilitating financial inclusion within the region. Moreover, GSM Association (Global System for mobile communications) press release report [4] suggest that more than half of all mobile money transfers globally are attributed to Sub-Saharan Africa and also found that most of these transactions have evolved from the sole purchase of airtime and person-to-person transfer, eventually expanded to include more sophisticated ones such as utility bill payments, payments to merchants and international remittances.

There are various mobile money service providers in Botswana like Orange with Orange Money, Mascom with Myzaka and BTC with SMEGA. According to annual reports 2018 of Botswana communications regulatory authority (BOCRA), market share of the Orange mobile money was 73 percent, followed by Mascom Wireless at 27 percent market share and BTC Mobile at 1 percent during the period under review [5].

Orange money revolutionized in the mobile money market by facilitating services such as local money transfers, international money transfers (to Zimbabwe only), money transfers to orange subscribers as well as Non-orange subscribers. Its fast, reliable and affordable services made it possible to increase the market share from $68 \%$ to $73 \%$ in one year [5].

Mobile money services can particularly be useful when purchasing items from shops, pay bills like electricity and water, top up mobile airtime and send money to another person. Moreover, cash withdrawals can also be carried out with authorized agents. Mobile money service has proved to be significant for locally based businesses with very little or low capital as well as those who do not fulfill the requirements of opening accounts and who fail to meet the threshold of traditional financial institutions [6].

Users can deposit and withdraw money from their wallets at authorized agents. Micro enterprises view mobile wallets as a flexible, affordable option to do transactions such as send and receive payments to suppliers, business partners and customers.

Many researchers have studied the role played by mobile money services and other related topics in countries such as Kenya, Tanzania, Uganda and Nigeria[6, 7], but the research on mobile money adoption in Botswana is scarce. This lack of research has led to a lack of awareness on the part of 
mobile service providers on how best to improve their facilities in order to reach a larger audience of participants through improved participation. A research report of a survey on 180 small businesses in five urban areas in Botswana states that two thirds of SME owners are not in favor of banks and for $73 \%$ instances they use cash to pay suppliers. It adds further to say SMEs need a range of affordable banking products - for making transactions, making payment of wages as well as access to all types of credit, from short to long term [8]. Small scale business owners become handicapped in accessing a readily developed technology within the African continent to improve their productivity and contribute more towards the economy[9]. Mobile money can be sought as a solution for the above problems. Therefore, this study sought to assess the utilization of mobile money services in the operation of small scale enterprises in Botswana.

The study was carried out with the following objectives:

- To find out the level of adoption of mobile money services within the operations of small scale enterprises in Gaborone

- To determine the types of transactions performed by small scale enterprises in Gaborone, using mobile money services

- To find out the main barriers faced by small scale enterprises in Gaborone in adopting the use of mobile money services in their operations

- To establish the significance of mobile money services in the overall performance of small scale enterprises in Gaborone

\section{LITERATURE REVIEW}

The significance of small scale enterprises in driving global economic growth has been documented by many academic authors in the last four decades [10, 11]. SMEs account for half of private sector employment in Botswana, employing about 220,500 people [8]. This section outlines some of the existing studies on mobile money adoption by small businesses in different countries. From the extant literature it is clearly evident that small enterprises use mobile money services mainly to perform transactions such as sending payments to suppliers and receiving payments from customers.

Ismail et al. studied to find out why the adoption of mobile money transfer services is low in rural parts of Kampala in Uganda, the results show that customer expectancy and behavioral intention of the user have a significant impact towards the use of mobile money services and transactional cost is found to have no significant impact [12].

Another study by Kirui and Onyuma [13] in Nakura town Kenya identified a positive significant relation between mobile money transactions on sales turnover MSE's. The study further recommended that decreasing the transaction costs for mobile money transactions and insurance companies agreeing to receive premium payments through mobile money services can significantly improve the adoption of technology.

Simiyu and Oloko [10] examined the impact of mobile money services on the performance of SME's and found that use of mobile money has made a significant contribution to SME sector. The study further reveals that majority of
SME's were using mobile money services for sending and receiving money from suppliers and customers respectively.

Similarly, Mashocha and Dzomonda [11] investigated the driving factors of mobile money services and their impact on performance of SME's in Zimbabwe. The results show that adoption of mobile money services influences the performance of SME's. The study identified perceived benefits of using mobile money and challenges in money transaction with traditional banking are driving factors for adoption of mobile money services in SME's. The perceived benefits being versatility, cost saving, time consumption and user-friendliness.

Mobile money adoption is driven by certain factors, Islam [14] investigated the drivers for adoption of mobile payments in Bangladesh by using TAM model and the results show that perceived ease of use and perceived usefulness are the drivers for adoption of the mobile payments and perceived risk and perceived costs are found to be the impeding factors.

\section{Methodology}

This study adopted a survey approach to collect the data. This involves asking people who are called respondents for information either verbally or through a written questionnaire to attempt to describe the cause of a particular activity.

\section{A. Sampling Scheme:}

The target population includes small scale enterprises within the Gaborone city area. The researcher used convenience sampling in order to obtain respondents for the study. However, care was taken to ensure that businesses chosen to constitute the respondents of the study were from different sectors of the economy and the sample resemble the total population and thus reduce biases and increase the validity of the results produced by the study. In this survey, a sample of 30 small scale enterprises was selected as respondents of the study. These consisted of small scale enterprise owners and managers in five business districts in Gaborone city.

\section{B. Sources of Information}

This study made use of primary and secondary data collection approaches. The primary data was collected through use of a questionnaire, whilst the secondary sources of data included publications made by other authors through journals, blogs, newspaper articles as well as releases made by institutions such as Statistics Botswana were used as guides to proceed with the investigation.

\section{Data collection Instrument}

Data was collected using the primary method. The questionnaire consisted of both open ended and closed ended questions in order to get a broader and deeper understanding from the respondents' views. The questionnaire was divided into three sections; the first section captured administrative details, the second captured the business structure and the nature of transactions whilst the last section sought to assess the utilization of mobile money on the enterprise's operations.

\section{Data Analysis}

Combinations of qualitative and quantitative techniques were used to analyze the collected data. Data collected will 
first need to be evaluated in order to detect and eliminate errors and omissions. This process should be done simultaneously with data collection during the field work. It will then be coded according to categorization for entry into computers for further data analysis. All data collected was entered into the computer for analysis.

The researcher manually transferred the responses from the questionnaires into a spreadsheet. For this study, Microsoft Excel Spreadsheet software was used.

A coding scheme was developed in order to analyze qualitative data from open ended responses from the questionnaire. A hierarchal coding scheme was developed according to the themes detected in the responses to all nonnumerical (non-interval/ratio level) data because a spreadsheet will only accept numerical data only[15]. Thereafter, the researcher has gone through each respondent's questionnaire in turn, adding in the codes. From then on this data was entered into the spreadsheet.

Descriptive statistics were used to show-case the basic features of the data inputted into the spreadsheet program. This is because descriptive statistics provide simple summaries about the sample and the measures. Together with simple graphics analysis, they form the basis of most quantitative analysis of data[15]. This enabled the researcher to establish whether there is a relationship between mobile money service usage and the operation of small scale enterprises and ultimately answer the research questions and fulfill the objectives of this study. The data was presented in tables and charts to give a visual depiction so that the discussion of findings from the data can become much easier and more convenient for the reader.

\section{DATA ANALYSIS}

\section{A. Response Rate}

Out of the thirty questionnaires distributed to small scale enterprises in Gaborone, only twenty-one (21) brought back successfully completed questionnaires. This represents $70 \%$ of the total population surveyed. The remaining 30\% nonresponse rate was as a result of incomplete questionnaires and missing or misplaced questionnaire forms.

\section{B. Characteristics of Respondents}

The first three questions in the questionnaire were concerned with determining the characteristics of the respondents' business. The first question was on the business type of the small scale business enterprise, while the second was about the number of employees in the business enterprise whilst the third was concerned with the average monthly turnover of the enterprise. These questions were meant to ensure that only small scale enterprises would constitute the respondents of the study.

Responses to Question 1 revealed that six (6) of the respondents were involved in the Retail business. This was the major business type at $29 \%$ of the total respondents. Marketing and Services business types had four (4) respondents each, representing $19 \%$ of all responses. Transport in conjunction with Tourism \& Hospitality carried a $9 \%$ respondent rate by contributing two respondents each. Three business types: Entertainment; Marketing; and Construction, each contributed $5 \%$ of responses which denotes to one (1) respondent.

Responses to Question 2 revealed that Most of the respondent small scale enterprises $(81 \%)$ had employees that range from $1-5$, while those with the ranges of $6-10$ and $16-20$ employees contributed $14 \%$ and $5 \%$ respectively.

Responses to Question 3 revealed that average monthly turnover or revenue of the business enterprises. The data revealed that most business enterprises $(38 \%)$ under review made an average monthly turnover of the range BWP (10 $001-25000$ ) having had eight (8) respondents, followed by those with an average between BWP (25 $001-50000)$ with seven (7) respondents, thus contributing $33 \%$ to responses. Businesses that made an average monthly revenue of BWP $(1-10000)$ contributed the least responses of six (6), 29\% of the respondents.

\section{Utilization of Mobile Money services:}

To a question on utilization of mobile money services, $81 \%$ of the respondents, seventeen (17), reported to using mobile money services in their business enterprise operations whilst 19\%, four (4) respondents reported that they did not use mobile money services in their business operations as shown in figure 1.

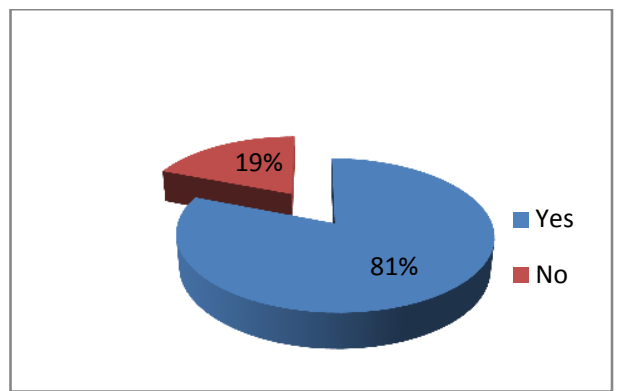

Figure 1: Utilization of Mobile Money services in business operations

\section{Most Used Mobile Money service}

Out of 21, eleven (11) respondents use Orange Money the most, five (5) respondents who mostly used both Orange Money \& Mascom MyZaka services in their business operations. Only one (1) respondent used only Mascom Myzaka for their business operations, whilst no respondents utilized bE Mobile Smega services.

\section{E. Frequency of Mobile Money transactions}

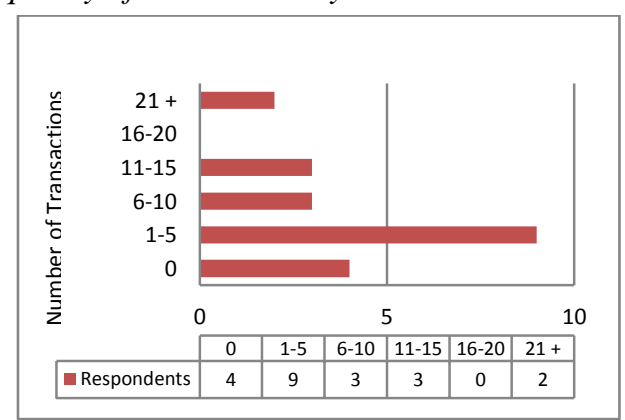

Figure 2: Frequency of mobile money transactions in a month

As depicted in figure 2, the responses show that 4 respondents do not make any monthly mobile money transactions and that 9 respondents, representing $43 \%$ of all respondent perform between $1-5$ transactions in a month. Moreover $11-15$ and 6-10 monthly transactions are each made by $14 \%$, three (3) respondents. Only two respondents make more than 21 transactions in a monthly basis. 


\section{F. Type of Mobile Money transactions}

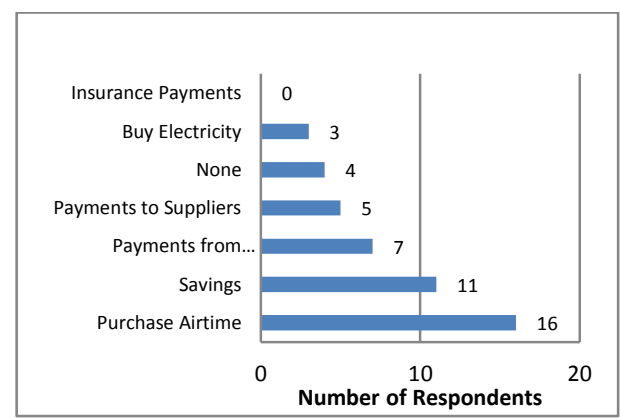

Figure 3: Type of Transactions performed using Mobile money

Small business owners in Gaborone use mobile money services to perform different transactions as shown in figure 3. The findings show that Purchase of Airtime is the most performed transaction by small scale enterprises with sixteen (16) respondents, followed by the use of the platform to perform saving functions for the enterprise reported by eleven (11) respondents. Seven (7) small scale enterprises in Gaborone report to using mobile money services to receive payments for goods and services from their customers. This represents $33 \%$ of the respondents.

However, only five (5), $24 \%$ report to using mobile money services to make payments to their suppliers whilst four (4) respondent do not perform any mobile money transactions. None of them responded to have used mobile money services to do insurance payments.

\section{G. Perception of the quality of services by Mobile Money Providers}

A question was on rating the quality of services by mobile money service providers. Respondents were given four options to choose the grade (poor, moderate, good, Excellent) of service rendered to them by mobile phone service providers. The following chart depicts the responses received on this question.

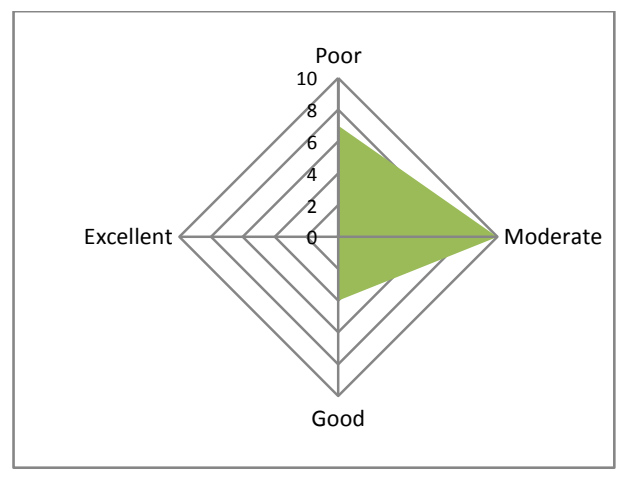

Figure 4: Mobile money service quality

As illustrated in figure 4 above, ten (10) respondents, representing $48 \%$, perceive the service rendered by Botswana's mobile money providers to be of moderate quality. Seven (7) of the respondents, which is $33 \%$ consider the services to be poor whilst only four (4), $19 \%$ believe the services are of a good grade. No respondent perceived the services to be excellent. A follow up open ended question to explain the rating was given, content analysis of the various responses shows 30 keywords of which 7 were positive describing time efficiently convenience and safety but remaining 23 were mostly referring to poor network quality for the low rating.

\section{H. Assessment Opinions of Mobile Money Services under Statement headings}

The respondents are provided 8 statements and were asked to indicate the extent to which they agree or disagree with a statement on a five point Likert scale with items Strongly agree(SA), Agree(A), Neutral(N), Disagree(D), Strongly disagree(SD). The statements and the responses received for the statements are given in Table I and Table II respectively.

\section{TABLE I: STATEMENTS}

Statements
1.Mobile money service has improved the business performance in its daily
operations
2. I intend to use mobile money services whenever they are available
3. Mobile Money Services come with many advantages to small scale
enterprises
4. Mobile Money Services provide convenience for small scale enterprises
5. Using Mobile Money Services allows a business enterprise to serve more
customers.
6. Mobile Money Services in Botswana should be improved to include more
services.
7. Using Mobile Money Services is extremely easy.
8. Mobile Money Services enable small scale enterprises to receive loan
services in order to expand their growth.
services in order to expand their growth.

\begin{tabular}{|c|c|c|c|c|c|c|c|c|c|c|}
\hline & & & & & $\mathrm{RE}$ & UN & & & & \\
\hline \multirow[b]{2}{*}{$\begin{array}{l}\text { statemen } \\
\mathrm{t}\end{array}$} & \multicolumn{2}{|c|}{ SA } & \multicolumn{2}{|l|}{ A } & \multicolumn{2}{|l|}{$\mathrm{N}$} & \multicolumn{2}{|l|}{ D } & \multicolumn{2}{|l|}{ SD } \\
\hline & $\begin{array}{l}\text { Fr } \\
\text { eq }\end{array}$ & $\%$ & $\begin{array}{l}\text { Fr } \\
\text { eq }\end{array}$ & $\%$ & $\begin{array}{l}\mathrm{Fr} \\
\text { eq }\end{array}$ & $\%$ & Freq & $\%$ & $\begin{array}{l}\text { Fre } \\
\text { q. }\end{array}$ & $\%$ \\
\hline 1 & 1 & 5 & 9 & 43 & 8 & 38 & 2 & 10 & 1 & 5 \\
\hline 2 & 3 & 14 & 11 & 52 & 4 & 19 & 3 & 14 & 0 & 0 \\
\hline 3 & 5 & 24 & 9 & 43 & 5 & 24 & 1 & 5 & 1 & 5 \\
\hline 4 & 2 & 10 & 14 & 67 & 3 & 14 & 2 & 10 & 0 & 0 \\
\hline 5 & 3 & 14 & 7 & 33 & 4 & 19 & 5 & 24 & 2 & 10 \\
\hline 6 & 15 & 71 & 3 & 14 & 0 & 0 & 1 & 5 & 2 & 10 \\
\hline 7 & 3 & 14 & 11 & 52 & 6 & 29 & 0 & 0 & 1 & 5 \\
\hline 8 & 1 & 5 & 0 & 0 & 5 & 24 & 8 & 38 & 7 & 33 \\
\hline
\end{tabular}

\section{Effects of Mobile Money Services on Business Operations}

Responses show that $43 \%$ of respondents are of the view that mobile money services have only positive effects on small scale enterprises' operations, whilst only $5 \%$ believe that they have only negative effects. However, $38 \%$ percent of them are of the view that they have both positive and negative effects on small scale enterprises' operations. Table III summarizes the responses that were obtained

TABLE III: RESPONSES ABOUT EFFECTS OF MOBILE MONEY SERVICES ON BUSINESS OPERATIONS

\begin{tabular}{|l|l|l|l|}
\hline Effect & Frequency & Percent & Cumulative Frequency \\
\hline Positive & 9 & $43 \%$ & $43 \%$ \\
\hline Negative & 1 & $5 \%$ & $48 \%$ \\
\hline Both & 8 & $38 \%$ & $86 \%$ \\
\hline None & 3 & $14 \%$ & $100 \%$ \\
\hline Total & 21 & $100 \%$ & \\
\hline
\end{tabular}

\section{J. Barriers of Mobile Money usage}

This was asked as open ended question, majority of the respondents opined that high costs of charges associated with use of mobile money services is biggest barrier for the adoption of mobile money services. 7 respondents believe 
that transactions tend to fail due to connectivity issues making mobile banking a viable option when compared to mobile money transfers. 5 responded that limited locations of services also hinder the use of mobile money. People also quoted security issues related to mobile money services impede the users from utilizing it. The low cash limit allowed on the account also proved to be a major deterrent in fully using mobile money services. Five (5) respondents expressed that their enterprise dealt with funds higher than the limit placed on the money account; hence they could not use it to perform functions such as payment of supplies. Furthermore, the same number of respondents argued that mobile money services were incompatible with other financial facilities such as bank accounts, and therefore cannot be accessed for business purposes.

\section{FINDINGS}

Small scale enterprises in Gaborone have adopted the use of mobile money services within their business operations, albeit using them to a limited extent. The type of transactions that can be utilized within these enterprises are largely limited to purchasing airtime and buying of electricity which is due to the limitation of large amount of funds not allowed on the mobile money account. Mobile Money Operators do not provide reliable network provision to allow small scale enterprises in Gaborone to use them in significant ways.

Moreover, small scale enterprises are discouraged from using mobile money services in their operations due to their high transactional charges. Other platforms such as Cell phone banking and the use of bank cards provide cheaper avenues which are accepted internationally and over a larger geographic spread than mobile money services which is vital as some suppliers of services are out of reach when using strictly mobile money services for transactional operations.

Most small scale enterprises in Gaborone reveal that mobile money transactions provide efficiency in their operations due to their ease of use and convenience. But they however regret that sometimes the services are not available hence there is unreliability with consistent use in their operations. The lack of compatibility was another main issue over the use of mobile money services as managers of small scale enterprises complained that because mobile money outlets are limited, it also tends to limit the access of funds over a certain time period.

Most respondents recommended a reduction in charge fees and the improvement of technology infrastructure to ensure that services were always available for small scale enterprises to use particularly in rural areas as some of their clients reside there

\section{CONCLUSION \& RECOMMENDATIONS}

Orange Money mobile money services has been found to be the mostly used services by most of small scale enterprises in Gaborone when compared to all the other services provided by other network providers. From the results obtained from the distributed questionnaires, the research concludes that $81 \%$ of small scale enterprises use mobile money services because they provide convenience and have a positive impact on the efficiency of their operations. However, the level of use of mobile money services is considerably low. Consequently, as observed by the perceived low level of quality offered by current mobile money service providers, the study concludes that small scale enterprises in Botswana are willing to use mobile money services but are largely let down by the infrastructure in the country.

The research recommends that mobile money service providers reduce the charges that are imposed on mobile money transactions, as this is one of the major reasons why small scale enterprises do not fully utilize the technology in their operations. The cost incurred in conducting mobile money services should be affordable to small scale enterprises when compared to what the banks normally charge for their bank transactions.

The research also suggests that mobile money service providers improve their infrastructure so as to build trust within the platform as most respondents in the study complained about the poor network connectivity to the service.

\section{REFERENCES}

[1] https://www.worldremit.com/en/faq/mobile-money

[2] Greenwood, L.: 'Africa's mobile banking revolution', in Editor $(\text { Ed. })^{\wedge}($ Eds.): 'Book Africa's mobile banking revolution’ (2009, edn.), pp.

[3] Hans Kuipers , M.M., and Michael Seeberg: 'Africa Blazes a Trail in Mobile Money: Time for Banks and mobile operators to devise strategies', in Editor (Ed. $)^{\wedge}($ Eds.): 'Book Africa Blazes a Trail in Mobile Money: Time for Banks and mobile operators to devise strategies' (2015, edn.), pp.

[4] 'Sub-Saharan Africa Driving Global Market for Mobile Money GSMA report', in Editor (Ed.)^(Eds.): 'Book Sub-Saharan Africa Driving Global Market for Mobile Money - GSMA report' (GSMA, 2017, edn.), pp.

[5] http://www.botswanaguardian.co.bw/business/item/3595-orangerules-mobile-money-market.html, Accessed : 9 November 2019

[6] Hughes, N., and Lonie, S.: 'M-PESA: mobile money for the "unbanked" turning cellphones into 24-hour tellers in Kenya', Innovations: Technology, Governance, Globalization, 2007, 2, (12), pp. 63-81

[7] Kabanda, S.: "E-Commerce Institutionalization is not for us": SMEs perception of E-Commerce in Tanzania', The African journal of Information systems, 2011, 3, (1), pp. 1

[8] http://www.sundaystandard.info/botswana\%E2\%80\%99s-smallbusinesses-held-back-lack-financial-services, Accessed November 2019

[9] Gencer, M.: 'The mobile money movement: Catalyst to jump-start emerging markets', Innovations, 2011, 6, (1), pp. 101-117

[10] Simiyu, C., and Oloko, M.: 'Mobile Money Transfer and the Growth of Small and Medium Sized Enterprises in Kenya: A Case of Kisumu City, Kenya', International Journal of Economics, Commerce and Management, 2015, 3, (5), pp. 1056-1065

[11] Masocha, R., and Dzomonda, O.: 'ADOPTION OF MOBILE MONEY SERVICES AND THE PERFORMANCE OF SMALL AND MEDIUM ENTERPRISES IN ZIMBABWE', Academy of Accounting \& Financial Studies Journal, 2018, 22, (3)

[12] Ismail, L., Moya, M.B., Bwiino, K., and Ismael, K.: 'Examining determinants of behavioural intention in adoption of mobile money transfer services in Uganda', ICTACT Journal on Management Studies, 2017, 3, (1), pp. 433-439

[13] Kirui, R.K., and Onyuma, S.O.: 'Role of mobile money transactions on revenue of microbusiness in Kenya', European Journal of Business and Management, 2015, 7, (36), pp. 63-67

[14] Islam, M.M.: 'An Investigation of Drivers and Barriers Stimulating in the Acceptance of Mobile Payment in Bangladesh', 2016

[15] Solace, S.: 'Inputting Data, and Creating Frequency Distributions', in Editor $(\text { Ed. })^{\wedge}($ Eds. $)$ : 'Book Inputting Data, and Creating Frequency Distributions’ (2014, edn.), pp. 


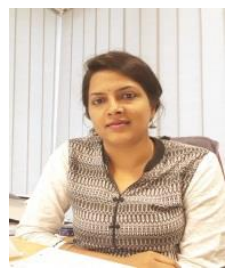

Suryakanthi Tangirala is a lecturer of Business Information Systems in Faculty of Business, Department of Accounting and Finance at University of Botswana. She holds a Ph.D. in Computer Science from Lingaya's University, India, and Masters of Computer Applications from Andhra University, India. Her current research interests are in areas of Information Systems, Information Management, Data Science and Big Data Analytics. She has published a number of papers in various refereed journals and conference proceedings.

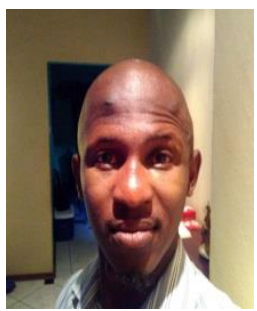

Samuel Nlondiwa holds a Bachelor of Finance degree from University of Botswana. His research interests include Cybercrime in finance, Financial risk management and Crypto currencies. 